PRZEGLĄD RUSYCYSTYCZNY 2021, nr 3 (175)

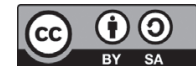

DOI 10.31261/pr.11537

\author{
MIROSŁAWA MICHALSKA-SUCHANEK \\ Uniwersytet Śląski w Katowicach \\ (iD) ORCID 0000-0001-5262-0816
}

\title{
PROZELITYCZNY WYMIAR PROZY ANNY FEIN
}

\author{
THE PROSELYTIC DIMENSION OF ANNA FEIN'S PROSE
}

\begin{abstract}
Anna Fein's works follow the trend of returning to the roots of Jewish culture and traditional Jewish spirituality. The writer links the national identity with religious identification. Her narrators-protagonists follow the path that she once went building Jewish self-awareness until conversion to Orthodox Judaism. In this evolution, which is the foundation of most of the writer's works' semantic-ideological dynamics, a kind of Fein proselytism is revealed. The proselytical nature of Fein's prose is also a derivative of the cognitive function, i.e., introducing the secular recipient to the orthodox community's world. The power of proselytizing resonance is also definitely strengthened by the autobiographical elements present in Fein's work.
\end{abstract}

Keywords: Russian-Israeli literature, proselytism, Jewish culture, Jewish religious identity, Orthodox Judaism

Anna Fein jest jedną z ciekawszych postaci literatury rosyjsko-izraelskiej. Urodziła się w 1963 roku w Moskwie, studiowała język angielski w Moskiewskim Państwowym Pedagogicznym Instytucie Języków Obcych imienia Maurice’a Thoreza. Po ukończeniu studiów uczyła języka angielskiego w szkole średniej, a także - jako aktywny członek nielegalnie działającego w Sowieckiej Rosji Związku Nauczycieli Hebrajskiego (Союз учителей иврита) - prowadziła tajne kursy języka hebrajskiego. Do Izraela wyjechała w roku $1991 \mathrm{w}$ ramach tzw. Wielkiej Aliii ${ }^{1}$ Obecnie wraz z mężem - nauczycielem Kabały

${ }_{1}$ Alija - powrót Żydów do ojczyzny swoich ojców. Wielką Aliją przyjęto nazywać masową imigrację z Rosji i republik związkowych do Izraela na przełomie lat 80. i 90., a zwłaszcza w latach 1990-1991. U schyłku lat 90. liczba byłych obywateli Związku Sowieckiego, którzy przekroczyli granicę państwa Izrael osiągnęła milion. Zob. m.in. R. Tarasiuk, Aspiracje polityczne społeczności rosyjskiej w Izraelu, https://repozytorium.uph.edu.pl/bitstream/handle/11331/1135/Tarasiuk. R_ Aspiracje_polityczne_spolecznosci.pdf?sequence $=1$ (30.01.2021). Z tej liczby ponad dwieście osób umieszczonych zostało na liście członków Związku Pisarzy 
- mieszka w ortodoksyjnym Bnei Braku. Działalność twórczą Fein łączy z pracą w Centrum Edukacji Żydowskiej, gdzie realizuje projekt skierowany do Żydów w diasporach pod wiele mówiącym tytułem „Żydowska rada pedagogiczna on-line”. Zbiór opowiadań Хроники третьей автопады $\iota^{2}$ wydany w roku 2004 w Odessie, jest jej pierwszą książką. Pisarka tworzy jak dotąd wyłącznie krótkie formy narracyjne, jej opowiadania drukowane są w Izraelu, w Rosji i na Ukrainie w takich czasopismach jak „Артикль”, „22” „Новая еврейская школа”, „Ами”, „Мигдаль”. Ostatnio jej utwory pojawiły się również na polskim rynku wydawniczym ${ }^{3}$.

Twórczość Fein stanowi interesującą literacką odsłonę - charakterystycznego dla repatriantów współistnienia teraźniejszej rzeczywistości izraelskiej i szeroko rozumianej pamięci o Rosji. Z Rosją - jak sama pisarka podkreśla - łączy ją jednak wyłącznie miejsce urodzenia, język, w którym myśli i pisze, kultura, którą kocha i ceni, oraz ciepłe wspomnienia dzieciństwa i młodości kojarzone z obrazami Parku Sokolniki i brzegów Jauzy. Nigdy - jak stwierdza - nie myślała o Rosji w kategoriach ojczyzny, przeciwnie - jest to kraj, który od zawsze rodzi w niej obawy ${ }^{4}$. Fein należy do tej grupy twórców, która szybko i jednoznacznie zadeklarowała tożsamościową przynależność do ziemi przodków, z „zaplecza rosyjskiego” czyniąc jedynie narzędzie opisu „nowego świata”. „Tu się urodziłam i zawsze mieszkałam w tym kraju"5 - mówi głosem narratorki Mesjasza dla śnieżynki (Meccuя для снежинки). W innym zaś miejscu dopowiada: „Urodziłam się tam, gdzie kiedyś narodził się mój naród. A urodzenie się mojego fizycznego ciała poza Izraelem jest nieporozumieniem"6.

Rosyjskojęzycznych Izraela. Zob. A. Lenart, Kultura literacka rosyjskojęzycznego Izraela. Spory wokót „narodowości” literatury, „Archiwum Emigracji: Studia Szkice - Dokumenty” 2014, z. 1-2 (20-21), s. 80.

2 Tytuły utworów nietłumaczonych na język polski podaję wyłącznie w oryginale. W przypadku przełożonego na język polski opowiadania Mesjasz dla śnieżynki posługuję się tytułem polskim.

3 Opowiadania Mesjasz dla śnieżynki i Trietiakowska psycholeria w przekładzie Mirosławy Michalskiej-Suchanek weszły do zbioru przekładów prozy rosyjskojęzycznych pisarzy izraelskich: M. Michalska-Suchanek, A. Lenart (wyb. i opr.), $Z$ Rosji do Izraela 2, Śląsk-Stowarzyszenie Inicjatyw Wydawniczych, Katowice 2020, a opowiadanie Niebiański Safed w przekładzie Alicji Mrózek opublikowane zostało w czasopiśmie „Iudaica Russica” 2020, nr 2(5).

4 Zob. M. Michalska-Suchanek, Беседа с Анной Файн, „Iudaica Russica” 2020, nr 2(5), s. 173.

5 A. Fein, Mesjasz dla śnieżynki..., s. 109.

6 M. Michalska-Suchanek, Беседа с Анной Файн... (tłum. moje - M.M.-S.) 
Fein od początku pracy twórczej podąża szlakiem wytyczonym niegdyś przez Eli Luksemburga i obecnie intensywnie wykorzystywanym przez Jakova Shechtera - powrotu do korzeni swojej kultury i żydowskiej tradycyjnej duchowości. Fabułę swoich utworów pisarka zwykle sytuuje w środowisku religijnych Żydów - wychodźców z byłego Związku Sowieckiego. Jej narratorki-bohaterki przemierzają drogę, którą niegdyś przeszła ona sama - budowania/odradzania się żydowskiej samoświadomości, poszukiwania Boga, wreszcie nawrócenia się na ortodoksyjny judaizm. Ewolucja ta stanowi fundament semantyczno-ideowej dynamiki większości utworów Fein, co z powodzeniem można odczytywać jako próbę pomocy odbiorcy w odnalezieniu - jak w Mesjaszu dla śnieżynki - metaforycznego klucza do furtki prowadzącej do nowego duchowego świata. Ujawnia się w tym swojego rodzaju prozelityzm Fein, który chwilami ociera się o „propagandę” wiary.

Wspomniane opowiadanie stanowi - jak się wydaje - modelowy przykład tego zjawiska. Jego narratorka i jednocześnie bohaterka o imieniu Sasza reprezentuje biografię typową dla bohaterek Fein: urodziła się w Moskwie, tam ukończyła studia i poznała przyszłego męża, razem wyjechali do Izraela. Narracja prowadzona jest w dwóch planach: retrospektywnym (impresje z dzieciństwa, początki związku z przyszłym mężem, charakterystyka środowiska moskiewskich Żydów) i teraźniejszym (trudy życia w nowym kraju, rozwód, próby poradzenia sobie z nową sytuacją, w końcu odnalezienie siebie i swojego miejsca na ziemi). Na tle realiów Sowieckiej Rosji i później Izraela rozwija się opowieść o poszukiwaniu przez bohaterkę swoich korzeni i własnej drogi (w jej przypadku pojęcia są tożsame). Do prawdy o sobie samej zbliżają ją z jednej strony przywoływane kluczowe wydarzenia z przeszłości, obrazy wydobywane z zapomnienia w wyniku rozplątywania „magicznych nici pamięci” (motyw ten stanowi zabieg uzasadniający pojawianie się retrospektywnych impresji; pełni też kluczową rolę w odsłonięciu finalnej idei utworu), z drugiej zaś magiczność mijanego codziennie w drodze do pracy miejsca - odgrodzonego od reszty miasta osiedla chasydzkiego. Początkowe zaciekawienie świeckiej kobiety życiem ortodoksyjnych Żydów wkrótce zamienia się w irracjonalną, pozarozumową fascynację tym światem. Osiedle bohaterka zaczyna postrzegać jako substytut pierwotnego porządku, oazę spokoju, cichą (idealną) wyspę w zgiełku i chaosie otaczającego ją miasta: „[...] удивлялась, как не похож остров на разлитое вокруг израильское море”. Widniejący przy wejściu na

7 А. Файн, Мессия для снежинки, w: tejże, Хроники третьей автопады, Еврейский Общинный Центр „Мигдаль”, Одесса 2004, s. 55. 
osiedle plakat $\mathrm{z}$ wizerunkiem starego rabina $\mathrm{w}$ czarnym kapeluszu, siwą brodą i wyciągniętą dłonią, opatrzony napisem: „Царь-Мессия залечит все раны"8 rekapituluje charakter miejsca, stanowiąc jednocześnie zaproszenie i obietnicę.

Osiedle, nazwane przez Saszę „wyspą”, staje się impulsem, pod wpływem którego z pamięci bohaterki wydobywa się jej pierwotne wspomnienie. Jest nim przedszkolna zabawa noworoczna, podczas której rudej Saszy o obco brzmiącym nazwisku Szumacher wyznaczono miejsce w jednolitym tłumie nic nie znaczących „śnieżynek”, co a priori określiło jej los i w jakimś sensie naznaczyło: „Кто и когда записал меня в снежинки, вечные статистки, безнадежный кордебалет? Кто внушил чувство ущербности, заставил играть по чужим правилам?”. Wspomnienie to jednoznacznie typuje zdarzenie, które przyjmuje rolę sytuacji generatywnej, władnej powołać do życia wyobrażeniowy model rzeczywistości oczekiwanej. Kluczowe zdarzenie z dzieciństwa bohaterka, w przestrzeni na pół magicznej, na pół onirycznej, przeżywa na nowo i inaczej, co jej życiu nadaje alternatywny (wreszcie właściwy!) kierunek. Powraca scena przedszkolnego balu, tyle że teraz elementy kulturowo rosyjskie zastąpione są żydowskimi. Zamiast Nowego Roku dzieci świętują Chanukę, ruda Sasza - tym razem wyróżniona, a nie „naznaczona” - otwiera korowód dziewczynek przebranych za chanukowe świece. Obraz wieńczy deklaratywna (dość nawet patetyczna) konstatacja - wcześniej już częściowo cytowana: „Я здесь родилась и всегда жила в этой стране. Я была свечой, я была кусочком огня, рыжим камнем стены” Generatywny potencjał pierwotnego wspomnienia umożliwia bohaterce powtórne przeżycie fundamentalnego dla jej własnej biografii zdarzenia w okolicznościach kulturowej translokacji, co przypieczętowuje jej narodową/religijną tożsamość. W tym kontekście kluczowego znaczenia nabiera symboliczna scena zamykająca opowiadanie. Rzecz dzieje się w teraźniejszości bohaterki, od chasydzkiego osiedla oddziela ją zamknięta na klucz furtka i pozostaje ją tylko otworzyć. „Вообрази ключ, - сказала она про себя, - и поворачивай, не переставая, пока не откроется" ${ }^{11}$.

W kreowanym przez Fein świecie zakodowany jest silny imperatyw powrotu do judaizmu. Przeważnie - jak w Mesjaszu dla śnieżyn-

8 Tamże, s. 77.

9 Tamże, s. 76.

${ }^{10}$ Tamże, s. 77.

${ }^{11}$ Tamże, s. 80. 
$k i$ - jest to długa, złożona i bolesna droga poszukiwań, bywa jednak, że metanoja nabiera charakteru mistycznego, jak w ujawniającym silne nacechowanie prozelityczne opowiadaniu Колодец перевоплощений ${ }^{12}$.

Bohaterką opowiadania Fein czyni Gelę, świecką, trzydziestoletnią repatriantkę z Rosji. Jej zafascynowany Kabałą partner z iście misjonarskim zapałem usiłuje wprowadzać ją w rudymenty życia środowiska religijnego. Podsuwaną literaturę o charakterze agitacyjnym (Fein używa słowa „агитка”), która nawołuje do powrotu do religii i odsłania tajniki nowej dla Geli obyczajowości, ta niestety odbiera jako: „пошловатую бурду - компот с прокисшими тряпками” ${ }^{13}$. Główny ciężar prozelityczny utworu spoczywa jednak na scenie rozmowy Geli z narratorką opowiadania, kobietą ortodoksyjną, której zapał agitacyjny odnotowany jest wprost: „я впала в агитаторский ряж и забыла о блинах, подгорающих на сковородке"14. Dyskurs narratorki łączy konwencję bajki, rzeczowość i pragmatykę oraz wymiar mistyczny. Z jednej strony opowiada ona historię cudownej, dokonanej w mykwie, przemiany biednej kobiety w rusałkę, którą amerykański bogacz zabiera własnym samolotem do siebie do domu, aby ją tam odczarować, ona zaś z wdzięczności rodzi mu już osiemnaste dziecko. Z drugiej - mamy rzeczowy przekaz o użytkowych zaletach mykwy jako o miejscu, które daje wytchnienie od codziennych obowiązków i pozwala na poświęcenie czasu wyłącznie sobie:

в микву придешь, сядешь в ванночку... Дверь замкнешь на блестящий такой ключик... Ни один звук не проникает с улицы, и никто, никто тебя не трогает. Сидишь хоть час, хоть два, никто в дверь не колотится, не орет. А ты ногти себе обрезаешь и думаешь: как это законы Творения проявляются во всем, даже в самых пустяковых и дурацких вещах ${ }^{15}$.

I wreszcie opowieść narratorki koncentruje się na istocie rytuału, który stanowi zaczątek nowego życia, duchowe odrodzenie.

Присядешь - и колени плывут ко лбу, пятки отрываются от пола, и вся ты на минуту превращаешься в эмбрион, зародыш в чреве матери, а миква

${ }^{12}$ Utwory Anny Fein są zamieszczane głównie w Internecie. Pojawiają się równocześnie na wielu stronach, trudna jest więc do ustalenia data ich pierwszej publikacji - z tego też powodu tytuły nie są opatrzone datami.

${ }_{13}$ А. Файн, Колодец перевоплощений, https://www.sunround.com/club/journals/16fain.htm (29.01.2021).

14 Tamże.

15 Tamże. 
становится материнской утробой, вода - околоплодными водами. Тут-то ты и рождаешься заново. Ведь в тебе умерло самое твое главное, женское. В микве оно рождается снова, а вместе с ним - и ты вся, твоя душа, твое тело. [...]

Ноги оторвались от пола, колени и лоб поплыли навстречу друг другу, и она застыла в невесомости. Мир растаял в воде. [...] Она попыталась встать, цепляясь за водные потоки, выпрямилась и родилась снова $[. . .]^{16}$.

Obraz cudu przemiany ewoluuje od oglądu „fizjologicznego” (motyw dziecka w łonie matki) po wymiar mistyczny (cud narodzin tym razem o nie-ziemskiej proweniencji). Prozelityczną wymowę sceny wieńczy - celowo niewyszukany, co gwarantuje jego czytelność symboliczny obraz. Bohaterka wychodzi z mykwy i wiedziona tajemną wewnętrzną siłą wspina się na wzgórze. Tam, stojąc przy starej budowli, synagodze lub jesziwie (oczywisty symbol), obserwuje światła Bnei Braku i Ramat Ganu (również przekaz jednoznaczny, miasta te bowiem zamieszkuje społeczność ortodoksyjna), za którymi w oddali rozciąga się morze, tu utożsamiane z nowym życiem.

Fein w konstrukcji swoich bohaterek odwołuje się do szczególnej formy pamięci, którą umownie nazywa się prapamięcią czy pamięcią etniczną, tj. przenoszoną z pokolenia na pokolenie pamięcią o żydowskich korzeniach, o prahistorii, o religii. Co za tym idzie zakłada, że w każdym przedstawicielu narodu żydowskiego prędzej czy później ujawni się imperatyw powrotu do wiary przodków, bowiem a priori jest na to skazany.

Łączenie identyfikacji narodowej z religijną najwyraźniej (wręcz propagandowo) wybrzmiewa w niewielkim szkicu Память о Юле. Tytułowa Jula prezentuje kolejną odsłonę biografii kobiet w prozie Fein: tożsamościowe odrodzenie w rezultacie świadomej decyzji, mające miejsce jeszcze w okresie przedrepatriacyjnym (a więc wcześniej niż w przypadku bohaterek przywołanych wyżej), umacnianie poczucia przynależności narodowej poprzez działania na rzecz krzewienia w Rosji kultury żydowskiej (szkoła dla dzieci rosyjskich Żydów), wyjazd z dwójką dzieci z Rosji do Polski w ramach wizy turystycznej i dalej specjalnym samolotem do Izraela, trudne początki w nowym kraju, imanie się każdej pracy, żeby tylko przetrwać. Chociaż po przyjeździe do Izraela zaproponowano Juli życie w środowisku świeckim, bez wahania wybiera religijne, wytrwale i konsekwentnie podążając raz obraną drogą, opartą na wierze, samoedukacji i samodoskonaleniu:

${ }^{16}$ Tamże. 


\section{PROZELITYCZNY WYMIAR...}

Юля не „вдарилась” в религию, как другие, не сорвалась в нее, как в реку с обрыва. Ее глубокая вера проявилась постепенно, как изображение на фотоснимке, проступило сквозь мистический взгляд на вещи, свойственный ей смолоду, сквозь оптимизм, ставший основой упования на Творца мира ${ }^{17}$.

Fein kreśli dalsze losy bohaterki - Jula wychodzi za mąż, rodzi jeszcze czworo dzieci, tworzy wielodzietną (wzorcową) religijną żydowską rodzinę. Z poświęceniem prowadzi ulpan ${ }^{18}$ dla „rosyjskich” dziewcząt, gdzie wprowadza je w tajniki judaizmu, dba o ich codzienne życie i stara się organizować przyszłość: „[...] приемыши еврейского народа. Россия отвергла их, а Израиль принял руками Юли и любил их Юлиным сердцем"19.

Aktywną działalność bohaterki przerywa śmierć w wypadku samochodowym. Nie bez przyczyny ostatnią jej lekturą Fein czyni parszę ${ }^{20}$ Chaje Sarah poświęconą życiu Sary - żony Abrahama. Przypomnijmy - pojawia się ona w Księdze Rodzaju w opowieściach o losach patriarchy Izraela. Chociaż w tradycji żydowskiej rozmaicie ujmuje się rolę Sary, współcześnie utrwaliło się postrzeganie jej w kontekście najnowszej historii narodu żydowskiego i państwa Izrael jako „żony pioniera”. Sara wraz z mężem opuściła miasto i rodzinę, udała się w podróż w nieznane i wystawiała się na próby, jakie niesie życie na pustyni. Zgodnie z przekazem Abraham, gotowy na męczeństwo, przestrzegał Tory na długo przedtem, zanim została ona przekazana Mojżeszowi, zwalczał kult obcych bożków i pozyskiwał pogańskich mężczyzn jako konwertytów dla wiary w Boga. Sara natomiast z oddaniem krzewiła religię wśród kobiet. W erze przedchrześcijańskiej judaizm funkcjonował jako religia misyjna, rys ten zanikł dopiero po transformacji dokonanej przez rabinów w czasach narodzin chrześcijaństwa i zburzenia Świątyni Jerozolimskiej. Czyny Abrahama i Sary stanowiły więc przykład i zachętę do pozyskiwania spośród pogan nowych gorliwych wyznawców religii żydowskiej ${ }^{21}$. Przeprowadzenie

${ }^{17}$ А. Файн, Память о Юле, http://www.sunround.com/club/22/147_fain.htm (30.01.2021).

${ }^{18}$ Ulpan - szkoła, w której dorośli imigranci do Izraela intensywnie uczą się języka hebrajskiego.

${ }^{19}$ А. Файн, Память о Юле... W twórczości Fein często pojawiają się odniesienia do antysemityzmu w Rosji lat 8o., i to jest właśnie jeden z tych przypadków.

${ }^{20}$ Parsza jest tekstem interpretującym Torę. Liczba parsz (54) wynika z liczby tygodni, jakie mieści rok księżycowy. Chaje Sara też Chajej Sarah, Chaye Sarah lub Hayye Sarah - w tłumaczeniu z języka hebrajskiego oznacza „życie Sary”.

${ }^{21}$ Zob. W. Chrostowski, Matriarchinie Izraela $w$ tradycji żydowskiej, „Biblica et Patristica Thoruniensia" 2011, nr 4, s. 66-69. 
paraleli między „pramatką” narodu żydowskiego i Julą wynosi bohaterkę do rangi „kultowej” krzewicielki wiary i tym samym wzmacnia prozelityczne przesłanie utworu. „Подобно праматери Саре, она создавала новые души, приближая людей к единому”22 - czytamy w zakończeniu opowiadania.

T.S. Eliot stwierdza, że jeśli twórcy we własnej „produkcji literackiej" wyznaczają sobie zadanie krzewienia religii, a ich pisarstwo nosi znamiona „propagandowego” czy „agitacyjnego”, z powodzeniem można ich twórczość kwalifikować jako literaturę religijną ${ }^{23}$. Wychodząc z tego założenia, pisarstwo Fein uznać należy za taką właśnie literaturę. Ta konstatacja wymaga jednak, jak się wydaje, dookreślenia.

Religijność zwyczajowo pojmuje się jako rodzaj wtajemniczenia, nierzadko bliskiego objawieniu, tymczasem Fein rzecz upraszcza, mówi o wierze bez wgłębiania się w jej substancjalność, a kontakt $\mathrm{z}$ transcendencją sprowadza do wymiaru ludzkiego. W jej prozie religia nie jest tożsama $\mathrm{z}$ tajemnicą (w irracjonalne czy nawet mistyczne nacechowanie Fein wyposaża jedynie sam mechanizm duchowej przemiany), lecz raczej z zewnętrznym owej tajemnicy przejawem. Jest to styl (model) życia, wynikający z postrzegania świata i bycia-w-świecie zgodnie z samoidentyfikacją i tożsamościową deklaracją. Drogę pisarki do judaizmu wyznaczyło - jak sama twierdzi - zderzenie pędu do zakazanego, ale i nieosiągalnego w czasach sowieckich zachodniego stylu życia, opartego na konsumpcyjności, z życiem religijnym. W tym starciu hedonizm przegrał, tj. jak z właściwym sobie humorem zauważa sama Fein: „pejsy pokonały pepsi”24.

Wiara dla autorki Mesjasza dla śnieżynki jest odkrywaniem esencjonalnego, naturalnego porządku otaczającego świata. „Jesteśmy wydani na pastwę chaosu, który mieszka w świecie i w naszym wnętrzu"25 - powiada Przemysław Dakowicz. Pisarka jest przekonana, że życie religijne zwyczajnie ten chaos porządkuje ${ }^{26}$. Bohaterka ороwiadania Нахальная квартирантка ро przyjeździe z Rosji powoli wrasta w kulturową i religijną rzeczywistość Izraela. Uczy się modlitw według Siduru, ubiera się zgodnie z nakazami religii, aż

\footnotetext{
${ }^{22}$ А. Файн, Память о Юле...

${ }^{23}$ T.S. Eliot, Literatura a religia, przeł. J. Piasecka, w: H. Krzeczowski (opr.), Nowa krytyka. Antologia, Państwowy Instytut Wydawniczy, Warszawa 1983, s. 94.

${ }_{24}$ M. Michalska-Suchanek, Беседа с Анной Файн...

${ }^{25}$ P. Dakowicz, Obcowanie. Manifesty i eseje, Wydawnictwo Sic!, Warszawa 2014, S. 332.

${ }^{26}$ Zob. M. Michalska-Suchanek, Беседа с Анной Файн...
} 
przychodzi moment, kiedy podejmuje ostateczną decyzję: „дала себе клятвенное обещание окончательно перейти к ортодоксальному иудаизму" ${ }^{27}$. Czyni to w pełni świadomie, w jakimś sensie kierując się pragmatycznym podejściem do otaczającej rzeczywistości. Koszerny model życia zakłada filtrowanie myśli i bodźców płynących z pogrążonego w chaosie świata, więc tym samym - w przekonaniu bohaterki - ją przed tymże chaosem ochroni.

Tradycyjna identyfikacja religijności dzieła literackiego wynika z intencjonalnej interpretacji, opartej na rozpoznaniu w nim pierwiastków przejętych z religii i uznaniu ich za podstawowy budulec sensu utworu ${ }^{28}$. Kluczowe jest przy tym zdefiniowanie tych pierwiastków, często znaczeniowo złożonych i nieprzejrzystych. Biorąc pod uwagę wieloaspektowość, wieloznaczność i stopniowalność religijności tekstu, zasadne wydaje się przyjęcie tezy Marii Jasińskiej-Wojtkowskiej, że „przestrzenie literatury nasycone są różnoraką religijnością", i w następnej kolejności podążenie za jej postulatem rozciągnięcia „badawczego włoka”"9. Rozszerzone spektrum znaczeniowe pojęcia religijności literatury pozwala na postrzeganie go w ujęciu funkcjonalnym, to znaczy jako terminu systematyzującego, i, co ważne, określającego założoną przez autora utworu strategię odbioru tekstu. W przypadku prozy Fein nastawioną na odbiór światopoglądu religijnego.

Pierwiastki religijne w opowiadaniach autorki Mesjasza dla śnieżynki nie mają charakteru tradycyjnego, daleko im też do jednoznaczności. Pisarka posługuje się rodzajem „maski” czy inaczej „przesłoną mowy"30, która pozwala na przekazanie odbiorcy tego, co nazwać można rozpoznaniem wiary, bez stosowania mowy wprost ${ }^{31}$. Sławomir i Teresa Cieślikowscy zabieg ten nazywają „techniką sugestii ekspresji pośredniej” ${ }^{2}$. Nie odwołuje się ona do idei numinotycznych, jej

${ }_{27}^{27}$ А. Файн, Нахальная квартирантка, http://www.sunround.com/club/22/ 22_175_fain.htm (30.01.2021).

${ }^{28}$ Zob. M. Jasińska-Wojtkowska, Problemy identyfikacji religijności dzieła literackiego, w: J. Gotfryd, M. Jasińska-Wojtkowska, S. Sawicki (red.), Sacrum $w$ literaturze, Towarzystwo Naukowe Katolickiego Uniwersytetu Lubelskiego, Lublin 1983, s. 53 .

${ }^{29}$ Zob. tamże, s. 57.

${ }^{30}$ Zob. S. Cieślikowski, T. Cieślikowska, Sacrum i maska czyli o wypowiadaniu niewypowiedzianego, w: J. Gotfryd, M. Jasińska-Wojtkowska, S. Sawicki (red.), Sacrum $w$ literaturze..., s. 73.

${ }^{31}$ Zob. tamże.

${ }^{32}$ Zob. tamże. 
zadaniem jest skłonienie odbiorcy do namysłu nad możliwością innego niż dotąd funkcjonowania w świecie poprzez figuratywne przedstawienia, opisy codziennych przedmiotów, zwyczajnych zachowań, uczuć i emocji. Projektowany rezultat stosowania „maski” i jednocześnie naturalny probierz jej skuteczności stanowi „oddźwięk”. Termin nie jest równoznaczny z mechanizmem rozumienia, które ma charakter receptywny, więc w zasadzie bierny, przeciwnie - zakłada aktywność odbiorcy dzieła, polegającą na konstruowaniu semantycznej nadbudowy utworu. Rodzą się myśli, sensy, uczucia pobudzane przez tekst, lecz w nim nie zawarte, słowem wyzwala się - zaprojektowane przez nadawcę (autora) - emocjonalno-ideowe zaangażowanie odbiorcy, które uaktywnia postawę otwartości na alternatywny sposób bycia-w-świecie. Fein wnosi do świata przedstawionego treści, które nadają mu nowe znaczenia, redefiniują go i reinterpretują, ws kazują możliwość usytuowania siebie w nim na nowo.

Wydźwięk prozelityczny jest w dużej mierze pochodną funkcji poznawczej - w twórczości Fein niezwykle wyraźnej. Pisarka często sytuuje wydarzenia w Bnei Braku i Safedzie - miastach zamieszkałych prawie wyłącznie przez społeczność religijną. Z dbałością o detale przybliża tradycje żydowskie i podstawowe prawa judaizmu. Przywołane wyżej opowiadanie Колодец перевоплощений należy do utworów pisarki w tym aspekcie reprezentatywnych, zwłaszcza w części, w której w wypowiedź narratorki wplecione są precyzyjne (wręcz encyklopedyczne) informacje o rodzajach mykw, ich nazwach i kształtach. Funkcja poznawcza najpełniej ujawnia się jednak w kluczowej scenie opowiadania, kiedy bohaterka po raz pierwszy w życiu udaje się do mykwy. W opisie rytualnych czynności i samego miejsca pisarka posługuje się perspektywą osoby „z zewnątrz”, której brak wiedzy o znaczeniu czystości rytualnej, a przede wszystkim sceptycyzm, uzasadniają uszczegółowienie obrazu i jego eksplikację. Wymienione są zadania balanit (łaziebnej czuwającej nad poprawnością kąpieli rytualnej), a następnie kolejne wykonywane w mykwie czynności - od zwyczajowych pytań kierowanych przez balanit do kobiet odwiedzających mykwę, poprzez przygotowania do obrzędu (kąpiel, obcinanie paznokci etc.), po sam akt zanurzenia.

Fein nie pomija również innych fundamentalnych dla kultury żydowskiej tematów, jak choćby kaszrut, by wymienić np. opowiadanie Остров мифического пива z celowo wyeksponowanym motywem koszerności czy Kabała, np. w opowiadaniu Зеркало времени. $\mathrm{W}$ ostatnim z wymienionych utworów historia niejakiego rebe Arie 
staje się ponadto pretekstem do rozważań o miejscu i roli kobiet religijnych oraz o prawach żydowskich regulujących kontakty osób różnych płci.

Bohaterki Fein swoją „prozaicznością” odzwierciedlają ścieżki życiowe zwyczajnych żydowskich kobiet ortodoksyjnych oraz odsłaniają mechanizmy psychologiczne, społeczne i religijne, kształtujące dynamikę ich losu. Pisarka dotyka mikroświata domu, sfery życia osobistego, a także przyjmowanych przez kobiety ról społecznych z uwzględnieniem perspektywy historycznej, przestrzenno-geograficznej i związanej z tym specyfiki kultury, mentalności oraz tradycji. Proza Fein wprowadza świeckiego odbiorcę w codzienność typowej religijnej wielodzietnej rodziny z rozkrzyczanymi dziećmi, matką pochłoniętą domowymi obowiązkami i ojcem, oddającym się sprawom duchowym (np. Програмистка и ее демон). W ороwiadaniu Колодец перевоплощений rozmowę bohaterek bezustannie przerywają rozbawione dzieci, które matka co rusz upomina:

Миква, Геля, - это... Мендель, оставь Шейлу в покое! - пока я собиралась с мыслями, дети ворвались на кухню, - Шейла, не реви. Менди, мать твою, то есть, меня, чтоб мы оба были здоровы! Иди в свою комнату и не показывайся, пока я тебя не прощу. Шейла, лейкопластырь и йод на молочной стороне кухни... На молочной, тебе говорю. Вот видишь, Геля, как меня дети дергают?33

Wprowadzanie świeckiego odbiorcy (a to jest główny adresat twórczości Fein) w realia społeczności ortodoksyjnej nie da się odczytać inaczej niż jako nawoływanie do wsłuchania się w źródłową, pierwotną istotę własnego „ja”, którą pisarka bezwzględnie wiąże z judaizmem.

Sama Fein swoją prozę włącza w nurt post-ateistyczny, nadając terminowi własną interpretację. Post-ateista - konstatuje pisarka w odróżnieniu od osoby religijnej (ortodoksyjnej) nie odcina się od przed-religijnej przeszłości, przeciwnie - traktuje ją pragmatycznie, tj. przetransponowuje do obecnego życia i wykorzystuje jako instrument poznawania oraz wartościowania otaczającego świata ${ }^{34}$. W przypadku bohaterek Fein rzeczywiście mamy do czynienia z interesującą fuzją „starej” przedrepatriacyjnej mentalności i nowego spojrzenia na życie. Wizja teraźniejszego świata przepuszczona jest przez pryzmat

${ }_{33}$ А. Файн, Колодец перевоплощений...

${ }^{34}$ Zob. M. Michalska-Suchanek, Anna Fein, w: M. Michalska-Suchanek, A. Lenart (wyb. i opr.), Z Rosji do Izraela..., s. 87. 
świadomości repatriantki, która wyrastała w rosyjskiej kulturze, przesiąkała rosyjską (sowiecką) mentalnością. Jednocześnie wiedza o przeszłości jest starannie i konsekwentnie selekcjonowana, indywidualizowana i subiektywizowana, zgodnie z aktualnym postrzeganiem rzeczywistości i jej wartościowaniem ${ }^{35}$. John Tosh mówi $\mathrm{w}$ tym kontekście o pragmatyce działania pamięci ${ }^{36}$. Z jednej strony przeszłość weryfikują zdobywane latami doświadczenia i aktualne priorytety, z drugiej jednak nie bez znaczenia pozostają - mające źródło w przeszłości i przez to mocno zakorzenione - nawyki, które rewidują teraźniejszą postawę wobec świata. Pozostając w granicach wzorów zachowań ustalonych przez kulturę żydowską, Fein swoim bohaterkom pozwala na pewną swobodę zachowań indywidualnych (dotyczy to również samej pisarki). Ta szczególna jednia ateistycznych doświadczeń z przeszłości i żydowskich tradycji oraz religii skutkuje u Fein szczególnym rodzajem feminizmu (choć w przypadku kobiety religijnej brzmi to jak oksymoron). Jego istota tkwi w obronie (właściwie ochronie) kobiety, która żyje w społeczności ściśle regulowanej przez system zakazów i nakazów, przed bezwolnym poddawaniem się manipulacji ze strony własnego środowiska. Dzieje się to poprzez próbę nakłonienia jej do przyjęcia świadomej postawy wobec otaczającego świata, sprowadzającej się - w dużym uproszczeniu - do przekonania, że modlitwa, która nie jest podparta skutecznymi działaniami, nie stanie się antidotum na wszelkie życiowe problemy. Feminizm Fein zatem, przy jednoczesnym uprawianiu propagandy wiary, przyjmuje na siebie zadanie agitowania na rzecz świadomej drogi wewnątrz religii, drogi opartej na krytycyzmie, zdrowym rozsądku i trzeźwości ocen. Ze względu na wierność halasze nurt ortodoksyjny jest najbardziej ze wszystkich denominacji żydowskich odporny na zmiany. Typowa dla Fein postępowa narratorka/bohaterka-feministka, jako kobieta wywodząca się z środowiska religijnego, zdaje sobie sprawę z praw świata, w którym żyje, ale jest również świadoma, że status kobiet w ortodoksji ulega zmianie, a literatura $w$ tym procesie może i powinna odegrać znaczącą rolę.

${ }_{35}$ Zob. B. Szacka, Czas przeszły, pamięć, mit, Wydawnictwo Naukowe SCHOLAR, Warszawa 2006, s. 29.

${ }^{36}$ Zob. J.A. Jerochina, Pamięć $i$ wiedza o przeszłości jako formy bytowania świadomości historycznej, przeł. A. Stryjakowska, „Sensus Historiae” 2013, nr 2, vol. XI, s. 64, http://www.sensushistoriae.epigram.eu/index.php/czasopismo/ article/viewFile/139/136 (15.01.2020). 
Mimo że Fein reprezentuje środowisko ortodoksyjne, stanowisko, które zajmuje wobec świata, o jakim opowiada, należy określić jako trzeźwe i dalekie od fanatycznego. Typowe dla jej pisarstwa sarkazm, autoironia, komizm, a nawet czarny humor ugruntowują zdrowy dystans wobec siebie i świata ortodoksji. W kilkukrotnie wspominanym tu opowiadaniu Колодец перевоплощений pojawia się taki oto passus (wypowiedź narratorki o swojej świeckiej interlokutorce):

мне казалось, что Бней-Брак в ее представлении - клоака, где голодные дети рвут куски хлеба друг у друга изо рта, где вши ползают под париками замужних женщин, стены домов воняют помоями, льющимися прямо на головы прохожим, а из окна глядит смазливое личико еврейки, украшенное потемневшими бусами. А миква, уж конечно, - грязная лужа, вокруг которой копошатся старухи, трогающие холодными пальцами робкую плоть молодых женщин ${ }^{37}$.

Ten ironiczny obraz odzwierciedla pejoratywne, stereotypowe postrzeganie ortodoksów przez rosyjskojęzyczne izraelskie środowisko świeckie ${ }^{38}$. Co jednak istotne, utwór kończy się nawróceniem bohaterki, której myśli rejestruje narratorka, ostatecznie tym mocniej wybrzmiewa więc idea dla Fein programowa, wiążąca narodową identyfikację z religijną, tj. niezależnie od tego jak daleko - zdaje się mówić pisarka - Żydzi odeszli od religii przodków, i tak „skazani są” na powrót do niej.

Prozelityczne nacechowanie twórczości Fein w niemałym stopniu wynika również z charakteru więzi łączących pisarkę z rzeczywistością przedstawioną. Mamy tu do czynienia z typem literatury, której fikcjonalność wyznaczają biograficzno-egzystencjalne uwarunkowania autorki. Izraelski rosyjskojęzyczny odbiorca, który przeszedł podobną drogę z Rosji do kraju ojców, bez wątpienia ma podstawy do tego, aby identyfikować tożsamość pisarki i tworzonych przez nią postaci. Tym samym - i tu przyjmijmy rozumowanie Philippe'a Lejeune - zakreślona zostaje przestrzeń autobiograficzna tekstu, a z odbiorcą zawarty tzw. pakt fantazmatyczny, na mocy którego odsyłany jest on do fantazmatów, niosących kluczowe informacje o twórcy tekstu. A to w rezultacie sprawia, że przyjmuje z góry narzucony mu sposób lektury ${ }^{39}$.

37 А. Файн, Колодец перевоплощений...

${ }^{38}$ Zob. np. Е. Римон, Русский антисемитизм в Израиле, „Мастерская - журналгазета истории, традиции, культуры”, 25.08.2020, http://club.berkovichzametki.com/?p=57373 (30.01.2021).

${ }^{39}$ Zob. P. Lejeune, Pakt autobiograficzny, przeł. A. W. Labuda, „Teksty: teoria literatury, krytyka, interpretacja” 1975, nr 5 (23), s. 46. 
Do opowiadanych historii - zwłaszcza tych o charakterze retrospektywnym - pisarka włącza obrazy z własnego życia. Podobnie jak czyni to bohaterka Mesjasza dla śnieżki, Fein rozplątuje nić własnych wspomnień, aby za ich pomocą odsłaniać tajemnice losów tworzonych postaci. Całościowe spojrzenie na prozę Fein pozwala na zrekonstruowanie chronologii istotnych faktów z jej biografii, gdyż ich zbieżność z życiorysami narratorek-bohaterek jest bezsprzeczna. Zazwyczaj - podobnie jak ona - są repatriantkami z Moskwy, niejednokrotnie anglistkami (np. Mesjasz dla śnieżynki), w opowiadaniu Нахальная квартирантка narratorka jest lingwistką, absolwentką tej samej, wymienionej z nazwy, uczelni co Fein. Przed wyjazdem do Izraela, jeszcze w Moskwie - jak sama pisarka - nauczały języka hebrajskiego (np. narratorka opowiadania Память о Юле) ${ }^{40}$. W Izraelu bohaterki Fein przeważnie mieszkają, jak ona, w religijnym Bnei Braku (np. Тихая женщина с улищы Бешт lub Долив после отстоя), a ich mężowie, podobnie jak jej mąż, zajmują się Kabałą (m.in. Зеркало времени). Bohaterka Острова мифического пива publikuje swoje utwory w tel-awiwskim czasopiśmie, niewymienionym co prawda z nazwy, ale nietrudno się domyślić, że chodzi o znane rosyjskojęzyczne izraelskie czasopismo literackie „Артикль”, chętnie zamieszczające utwory Fein. Zwłaszcza, że w opowiadaniu wymienieni są z nazwiska jego główni redaktorzy (i jednocześnie pisarze) Jakov Shechter i nieżyjący już Michaił Judson. Ponadto w ostatnim z wymienionych utworów narratorka staje się odbiciem postaci pisarki: „И тут я увидела себя со стороны. Тетка, похожая на стареющего пирата, с головой, по-пиратски обмотанной шарфом и в пестрых греческих бусах из Линдоса [...]"41. Ten karykaturalny obrazek stanowi kwintesencję niebanalnego wyglądu i dość ekscentrycznej osobowości samej Fein ${ }^{42}$.

Kształtowanie narratorki/bohaterki w rolach bezpośrednio lub pośrednio odsyłających do rzeczywistej autorki buduje wrażenie pozaliterackiego autentyzmu. Literatura staje się w ten sposób zapisem

${ }^{40}$ Nauki języka hebrajskiego zakazano na mocy dekretu Narkomprosa w 1919 roku, i mimo gorbaczowowskiej pierestrojki lekcje wciąż prowadzono nieoficjalnie, w prywatnych mieszkaniach.

${ }^{41}$ A. Файн, Остров мифического пива, https://promegalit.ru/public/19392 anna_fajn_ostrov_mificheskogo_piva_travelog_iz_serii_pivnye_rasskazy.html (10.01.2021).

${ }^{42}$ Pisarka - bardzo aktywna w mediach społecznościowych - często zamieszcza swoje zdjęcia, które odzwierciedlają jej zamiłowanie do wymyślnych wiązań chusty na głowie i wyszukanej biżuterii. 
przestrzeni autorskiej, świat przedstawiony ukazany z konkretnej autorskiej perspektywy wychodzi poza swoją recepcję jako przedmiotu funkcjonującego wyłącznie w literackich odniesieniach i porządkach. W przypadku autorskiej podmiotowej obecności w tekście, odbiorca tworzy wizerunek nadawcy, buduje hipotezę jego przestrzeni życiowej i ją identyfikuje, rozpoznaje obowiązujący w niej system wartości. Ponadto określa pozycję, jaką nadawca w tej przestrzeni zajmuje, a także postulaty i zastrzeżenia, jakie wobec niej zgłasza ${ }^{43}$. Kolejny krok stanowi konfrontacja dwóch oglądów świata - cudzego (właśnie oto rozpoznawanego) i własnego. W zderzeniu tych przestrzeni (dwóch podmiotowych światów) ujawnia się identyczność lub konflikt punktów widzenia, a w rezultacie dokonywany jest akt afirmacji lub negacji ${ }^{44}$. Lektura tekstu odsłania zatem pewną potencjalność, m o żli w o ść, jest rozpoznawaniem i doświadczaniem siebie wobec osoby twórcy, którego wizje świata można odrzucić, albo zawłaszczyć. Jest to moment, w którym - jak w Mesjaszu dla śnieżynki - mamy do czynienia z sytuacją generatywną, wskazującą nowy (alternatywny) sposób bycia-w-świecie. Religijność literatury jest rodzajem świadectwa - im bardziej więc ukonkretniony jest podmiot owego wyznawstwa i zbliżony do osoby autora, tym silniej literatura ta staje się religijna w najściślejszym znaczeniu ${ }^{45}$.

Rekapitulując, proza Fein wyraźnie sytuuje się w prozelitycznym nurcie, który głosi powrót do korzeni żydowskiej kultury i tradycyjnej duchowości oraz odradzanie się żydowskiej samoświadomości. Tożsamość narodową pisarka programowo łączy z identyfikacją religijną (z judaizmem). Prozelityczny charakter twórczości Fein ujawnia się nie tylko w narracji o duchowej przemianie bohaterek, ale jest także w dużej mierze pochodną funkcji poznawczej i autobiografizmu tej prozy.

Religijność pisarstwa autorki Mesjasza dla śnieżynki potraktowana została jako czynnik funkcjonalny (systematyzujący), wskazujący na założoną strategię odbioru tekstów, nastawioną na odbiór światopoglądu religijnego.

${ }^{43}$ Zob. S. Chwin, S. Rosiek, Bez autorytetu, Wydawnictwo Morskie, Gdańsk 1981, s. 108.

${ }^{44}$ Zob. tamże, s. 109.

${ }^{45}$ Zob. M. Jasińska-Wojtkowska, Problemy identyfikacji religijności dzieła literackiego..., s. 6o. W przypadku, gdy między ogólną wymową religijną tekstu a rzeczywistą postawą pisarza jako człowieka zachowany jest duży dystans, religijność utworu utożsamia się ze stylizacją. Zob. tamże, s. 6o-61. 


\section{MIROSŁAWA MICHALSKA-SUCHANEK}

\section{REFERENCES}

Chrostowski, Waldemar. "Matriarchinie Izraela w tradycji żydowskiej." Biblica et Patristica Thoruniensia 2011, no. 4: 63-94.

Chwin, Stefan. Rosiek, Stanisław. Bez autorytetu. Gdańsk: Wydawnictwo Morskie, 1981.

Cieślikowski, Sławomir, and Cieślikowska Teresa. "Sacrum i maska czyli o wypowiadaniu niewypowiedzianego.” Sacrum w literaturze. Gotfryd, Jan. JasińskaWojtkowska, Maria. Sawicki, Stefan (Eds.) Lublin: Towarzystwo Naukowe Katolickiego Uniwersytetu Lubelskiego, 1983. 65-82.

Dakowicz, Przemysław. Obcowanie. Manifesty $i$ eseje. Warszawa: Wydawnictwo Sic!, 2014.

Eliot T.S. "Literatura a religia.” Transl. Piasecka, Joanna. Nowa krytyka. Antologia. Krzeczkowski, Henryk (Ed.). Warszawa: Państwowy Instytut Wydawniczy, 2014. 90-105.

Fein, Anna. "Messiya dlya snezhynki." Fein, Anna. Hroniki tret'ey avtopady. Odessa: Evrejskij Obŝinnyj Centr Migdal', 2004. 47-80 [Файн, Анна. "Мессия для снежинки.” Файн, Анна. Хроники третьей автопады. Одесса: Еврейский Общинный Центр Мигдаль, 2004. 47-80].

Fein, Anna. "Mesjasz dla śnieżynki." Transl. Michalska-Suchanek, Mirosława. $Z$ Rosji do Izraela 2. Michalska-Suchanek, Mirosława. Lenart, Agnieszka (eds.). Katowice: Śląsk and Stowarzyszenie Inicjatyw Wydawniczych, 2020. 89-111.

Fein, Anna. "Trietiakowska psycholeria.” Transl. Michalska-Suchanek, Mirosława. Z Rosji do Izraela 2. Michalska-Suchanek, Mirosława. Lenart, Agnieszka (eds.). Katowice: Śląsk and Stowarzyszenie Inicjatyw Wydawniczych, 2020. 112-118.

Fein Anna. "Niebiański Safed.” Transl. Mrózek, Alicja. Iudaica Russica 2020, no. 2(5): 181-184.

Fein, Anna. Kolodec perevoploŝenij.<https://www.sunround.com/club/journals/ 16fain.htm> [Файн Анна. Колодец перевоплощений.]<https://www.sunround.com/club/journals/16fain.htm > ].

Fein, Anna. Nakhal'naya kvartirantka. <http://www.sunround.com/club/22/ 22_175_fain.htm> [Файн Анна. Нахальная квартирантка.] <http://www. sunround.com/club/22/22_175_fain.htm>].

Fein, Anna. Ostrov mificheskogo piva. <https://promegalit.ru/public/19392_anna_fajn_ostrov_mificheskogo_piva_travelog_iz_serii_pivnye_rasskazy. html> [Файн Анна. Остров мибического пива. <https://promegalit.ru/public/19392_anna_fajn_ostrov_mificheskogo_piva_travelog_iz_serii_pivnye_ rasskazy.html >].

Fein, Anna. Pamyat' o Yule. <http://www.sunround.com/club/22/147_fain.htm> [Файн, Анна. Память о Юле. <http://www.sunround.com/club/22/147_fain. htm>].

Jasińska-Wojtkowska, Maria. "Problemy identyfikacji religijności dzieła literackiego.” Sacrum w literaturze. Gotfryd, Jan. Jasińska-Wojtkowska, Maria. Sawicki, Stefan (eds). Lublin: Towarzystwo Naukowe Katolickiego Uniwersytetu Lubelskiego,1983. 53-64.

Jerochina, Jelena A. "Pamięć i wiedza o przeszłości jako formy bytowania świadomości historycznej.” Transl. Stryjakowska, Anna. Sensus Historiae 2013, no. 


\section{PROZELITYCZNY WYMIAR...}

2. Vol. XI: 63-70. <http://www.sensushistoriae.epigram.eu/index.php/czasopismo/article/viewFile/139/136>.

Lejeune, Philippe. "Pakt autobiograficzny.” Transl. Labuda, Aleksander Wit. Teksty: teoria literatury, krytyka, interpretacja 1975, no. 5(23): 31-49.

Lenart, Agnieszka. "Kultura literacka rosyjskojęzycznego Izraela. Spory wokół 'narodowości' literatury." Archiwum Emigracji: Studia - Szkice - Dokumenty 2014, z. 1-2 (20-21): 80-90.

Michalska-Suchanek, Mirosława. "Beseda s Annoy Fein." Iudaica Russica 2020, no. 2(5): 173-180 [Michalska-Suchanek Mirosława. “Беседа с Анной Файн.” Iиdaica Russica 2020, no. 2(5): 173-180].

Michalska-Suchanek, Mirosława. "Anna Fein." Z Rosji do Izraela 2. MichalskaSuchanek, Mirosława. Lenart, Agnieszka (eds.). Katowice: Śląsk. Stowarzyszenie Inicjatyw Wydawniczych, 2020, 85-88.

Szacka, Barbara. Czas przeszly, pamięć, mit. Warszawa: Wydawnictwo Naukowe SCHOLAR, 2006.

Tarasiuk, Renata. Aspiracje polityczne spoteczności rosyjskiej w Izraelu. <Tarasiuk.R_Aspiracje_polityczne_spolecznosci.pdf (uph.edu.pl)>.

Rimon, Elena. "Russkij antisemitizm v Izraile." Masterskaya - zhurnal-gazeta istorii, tradicii, kul'tury. 25.08.2020. <http://club.berkovich-zametki. $\mathrm{com} /$ ?p=57373>. [Римон,Елена. “Русскийантисемитизм вИзраиле.” Мастерская - журнал-газета истории, традиции, культуры. 25.08.2020. <http:// club.berkovich-zametki.com/?p=57373>]. 